\title{
Are There Differences in Potency Between SGLT-2 Receptor Blockers Utilized in The Therapy of Heart Failure?
}

\section{David Bell* | Edison Goncalves}

*Correspondence: David Bell

Address: 1900 Crestwood Blvd, Suite 201, Irondale, AL 35210, USA

e-mail $\square$ : dshbell@yahoo.com

Received: 22 March 2021; Accepted: 26 March 2021

Copyright: (C) 2021 Bell DS. This is an open-access article distributed under the terms of the Creative Commons Attribution License, which permits unrestricted use, distribution, and reproduction in any medium, provided that the original work is properly cited.

\section{Commentary}

SGLT-2 receptor inhibitors, when used to treat type 2 diabetes, show differences in the achieved HbA1c when used in the same patients. In a retrospective study there was a decrease in HbA1c of $0.2 \%$ when patients were forced by third party payors to change from canagliflozin to empagliflozin (Bell and Goncalves, 2018). From a large database patients starting canagliflozin $300 \mathrm{mg}$ versus dapagliflozin 10 mg daily over six months had a $0.26 \mathrm{mg} \%$ significantly greater fall in HbA1c with canagliflozin (Blonde et al., 2018). The ability of canagliflozin to have a greater effect on the HbA1c than other SGLT-2 inhibitors is due to the $300 \mathrm{mg}$ dose being unique in that it's effects lasts for at least 24 hours which results in a greater daily urine glucose excretion (Plosker, 2014).

More recently the SGLT-2 inhibitors have been approved for use in the therapy of heart failure (HF). Dapagliflozin is approved for treatment of HF in both diabetic and non-diabetic subjects while canagliflozin has been approved to reduce the risk of hospitalization for HF in adults with type 2 diabetes, nephropathy and albuminuria (McMurray et al., 2019; Perkovic et al., 2019). Empagliflozin, while not receiving an indication for use in $\mathrm{HF}$, has been shown in a prospective study to reduce HF hospitalizations and cardiac death even when HF was not present at the start of the study (Fitchett et al., 2016). Based on these prospective studies we cannot compare the efficacy of the available SGLT-2 inhibitors in HF and differences may exist that are more significant than differences between SGLT-2 receptor therapy of hyperglycemia. In addition, effects other than an osmotic diuresis (weight loss, lowering of blood pressure, increased ketone production and utilization decreasing cardiac workload and blockade of the $\mathrm{Na}+\mathrm{H}+$ exchanger in the myocardium) of SGLT-2 inhibitors may differ between these compounds and result in differing potencies in the therapy of HF (Bell and Goncalves, 2019).

A single clinical observation has led us to question whether there could be differences in the 
efficacy of SGLT-2 receptor blockers in the treatment of HF. A 62-year-old white type 2 diabetic patient had well controlled type 2 diabetes (HbA1c 6.2\%) and adequately controlled HF (NYHA2) utilizing sacabritil/valsartan, carvedilol, spironolactone and canagliflozin had a toe amputation. For medicolegal reasons he was changed from canagliflozin $300 \mathrm{mg}$ daily to dapagliflozin $10 \mathrm{mg}$ daily. Following this change his NT-pro BNP (normal less than $125 \mathrm{pg} / \mathrm{ml}$ ) rose from $221 \mathrm{pg} / \mathrm{ml}$ to $891 \mathrm{pg} / \mathrm{ml}$. On returning to canagliflozin $300 \mathrm{mg}$ daily the NT-pro BNP dropped back to $238 \mathrm{pg} / \mathrm{ml}$ and on changing, again for medicolegal reasons, to empagliflozin $25 \mathrm{mg}$ daily his NT-pro BNP dropped to $164 \mathrm{pg} / \mathrm{ml}$ (normal less than $125 \mathrm{pg} / \mathrm{ml})$.

Was this decrease in myocardial function as measured by NP-pro BNP with dapagliflozin and which was corrected with both canagliflozin and empagliflozin, unique to this patient or was there evidence of the same phenomenon occuring in randomized controlled clinical trials? In the DEFINE-HF trial where $263 \mathrm{HF}$ subjects with or without diabetes and who had a low ejection fraction were randomized to either placebo or to dapagliflozin $10 \mathrm{mg}$ daily, there was a suggestion of an improvement in symptoms but no change in NT-pro BNP (Nassif et al., 2019). On the other hand, in a study of established class 2, 3, 4 NYHA heart failure in both diabetic and non-diabetic subjects with reduced ejection fraction, dapagliflozin 10 mg daily significantly reduced the NP-pro BNP by 46\% (196 to $101 \mathrm{pg} / \mathrm{ml}$ ) (McMurray et al., 2019). While from these results we might conclude, based on the biomarkers of HF, that the efficacy of dapagliflozin in HF is controversial, there is no doubt that the other SGLT-2 inhibitors reduce the biomarkers of HF.

Canagliflozin, in two human studies has clearly been shown to lower BNP in both Japanese and older patients with type 2 diabetes and chronic heart failure. NT-pro BNP was significantly $(\mathrm{p}=0.001)$ decreased with canagliflozin $100 \mathrm{mg}$ daily in 35 Japanese patients with HF and type 2 diabetes (Sezai et al., 2019). When 666 type 2 older diabetic patients with HF receiving either canagliflozin $100 \mathrm{mg}$ or 300 $\mathrm{mg}$, were compared with those receiving placebo canagliflozin over two years delayed the rise in serum NT-pro BNP and this effect was greater with the $300 \mathrm{mg}$ dose (Januzzi et al., 2017). In addition, in animal studies empagliflozin has been clearly shown to lower BNP (Shi et al., 2017).

Therefore, there is good evidence of a positive effect of canagliflozin and empagliflozin on cardiac biomarkers and conflicting evidence for dapagliflozin's effect. The only way this confusion could be reconciled is with "head to head" trials, rather than placebo-controlled trials, of the effects of different SGLT-2 inhibitors used in the therapy of HF. Until then the choice of an SGLT-2 inhibitor for the therapy of HF should be based on clinical judgement and monitored closely for changes in symptoms and cardiac biomarkers. Should the response to therapy be less than optimal, then changing to another member of the class would be justified. 
What is NOT justified is to exchange an SGLT-2 receptor inhibitor by anyone other than the treating physician. Therefore, when being utilized to treat HF, SGLT-2 receptor agonists should not be changed on the basis of cost or insurance coverage by pharmacists and/or third-party payors.

While SGLT-2 inhibitors can safely and justifiably be interchanged when being utilized to treat diabetes, only the treating physician should make the decision when these drugs can be exchanged for the therapy of HF.

\section{References}

Bell DSH and Goncalves E. Heart failure in the patient with diabetes: Epidemiology, aetiology, prognosis, therapy and the effect of glucose-lowering medications. Diabetes Obes Metab 2019; 21: 1277-1290.

Bell DSH and Goncalves E. Increase in glycated haemoglobin concentrations after unwarranted prescription changes. Diabetes Obes Metab 2018; 20: 2510-2511.

Blonde L, Patel C, Bookhart B, Pfeifer M, Chen YW, Wu B. A real-world analysis of glycemic control among patients with type 2 diabetes treated with canagliflozin versus dapagliflozin. Curr Med Res Opin 2018; 34: 1143-1152.

Fitchett D, Zinman B, Wanner C, Lachin JM, Hantel S, Salsali A, Johansen OE, Woerle HJ, Broedl UC, Inzucchi SE; EMPA-REG OUTCOME® trial investigators. Heart failure outcomes with empagliflozin in patients with type 2 diabetes at high cardiovascular risk: results of the EMPA-REG OUTCOME® trial. Eur Heart J 2016; 37: 1526-1534.

Januzzi JL Jr, Butler J, Jarolim P, Sattar N, Vijapurkar U, Desai M, Davies MJ. Effects of Canagliflozin on Cardiovascular Biomarkers in Older Adults with Type 2 Diabetes. J Am Coll Cardiol 2017; 70: 704-712.

McMurray JJV, Solomon SD, Inzucchi SE, Køber L, Kosiborod MN, Martinez FA, Ponikowski P, Sabatine MS, Anand IS, Bělohlávek J, Böhm M, Chiang CE, Chopra VK, de Boer RA, Desai AS, Diez M, Drozdz J, Dukát A, Ge J, Howlett JG, Katova T, Kitakaze M, Ljungman CEA, Merkely B, Nicolau JC, O'Meara E, Petrie MC, Vinh PN, Schou M, Tereshchenko S, Verma S, Held C, DeMets DL, Docherty KF, Jhund PS, Bengtsson O, Sjöstrand M, Langkilde AM; DAPA-HF Trial Committees and Investigators. Dapagliflozin in Patients with Heart Failure and Reduced Ejection Fraction. N Engl J Med 2019; 381: 1995-2008.

Nassif ME, Windsor SL, Tang F, Khariton Y, Husain M, Inzucchi SE, McGuire DK, Pitt B, Scirica BM, Austin B, Drazner MH, Fong MW, Givertz MM, Gordon RA, Jermyn R, Katz SD, Lamba S, Lanfear DE, LaRue SJ, Lindenfeld J, Malone M, Margulies K, Mentz RJ, Mutharasan RK, Pursley M, Umpierrez G, Kosiborod M. Dapagliflozin Effects on Biomarkers, Symptoms, and Functional Status in Patients with Heart Failure with Reduced Ejection Fraction: The DEFINE-HF Trial. Circulation 2019; 140: 1463-1476.

Perkovic V, Jardine MJ, Neal B, Bompoint S, Heerspink HJL, Charytan DM, Edwards R, Agarwal R, Bakris G, Bull S, Cannon CP, Capuano G, Chu PL, de Zeeuw D, Greene T, Levin A, Pollock C, Wheeler DC, Yavin Y, Zhang H, Zinman B, Meininger G, Brenner BM, Mahaffey KW; CREDENCE Trial Investigators. Canagliflozin and Renal Outcomes in Type 2 Diabetes and Nephropathy. $N$ Engl J Med 2019; 380: 2295-2306.

Plosker GL. Canagliflozin: a review of its use in patients with type 2 diabetes mellitus. Drugs 2014; 74: 807-824.

Sezai A, Sekino H, Unosawa S, Taoka M, Osaka S, Tanaka M. Canagliflozin for Japanese patients with chronic heart failure and type II diabetes. Cardiovasc Diabetol 2019; 18: 76.

Shi X, Verma S, Yun J, Brand-Arzamendi K, Singh KK, Liu X, Garg A, Quan A, Wen XY. Effect of empagliflozin on cardiac biomarkers in a zebrafish model of heart failure: clues to the EMPA-REG OUTCOME trial? Mol Cell Biochem 2017; 433: 97-102. 